\title{
Komunitas Mikroalga di Perairan Sungai dan Muara Sungai Pelangan Kecamatan Sekotong Kabupaten Lombok Barat
}

\author{
Widia Astuti ${ }^{1}$,Sri Puji Astuti ${ }^{1}$,Suripto ${ }^{1}$, Lalu Japa ${ }^{2}$ \\ ${ }^{1}$ Jurusan Biologi FMIPA Universitas Mataram, \\ ${ }^{2}$ Program Studi Pendidikan Biologi FKIP Universitas Mataram \\ ljapa@unram.ac.id
}

\begin{abstract}
Abstrak
Penelitian ini bertujuan untuk mengetahui komposisi, kemelimpahan, keanekaragaman serta dominansi jenis mikroalga yang terdapat pada perairan muara sungai Pelangan Desa Pelangan Kecamatan Sekotong Kabupaten Lombok Barat. Pada penelitian ini teridentifikasi 85 jenis mikroalga. Jumlah jenis paling banyak ( 24 jenis) teridentifikasi pada titik IV. Jenis yang mendominasi pada titik I dan II berdasarkan nilai pentingnya yaitu Chlorococcum humicola dengan persentase nilai penting pada masing-masing titik sebesar $72,309 \%$ dan $74,524 \%$, pada titik III jenis dengan nilai penting yang tertinggi adalah Coscinodisccus lacustris (55,024\%), pada titik IV nilai penting tertinggi dimiliki oleh Thalassiothrix fruenfeldii (15,795\%), dan pada titik V jenis dengan nilai penting tertinggi adalah Rhizosolenia sp dan Thalassiothrix fruenfeldii dengan persentase nilai yang sama yaitu sebesar $21,840 \%$. Jenis mikroalga yang selalu hadir pada semua titik pengamatan yaitu jenis Chlorococcum humicola dan Coscinodisccus lacustris. Indeks keanekaragaman jenis mikroalga tergolong dalam kategori rendah sampai sedang. Indeks keanekaragaman jenis mikroalga tertinggi terdapat pada titik IV yaitu $\left(H^{\prime}=3,010\right)$. Kemelimpahan total tertinggi tercatat pada titik II sebesar 1.540 ind/L.
\end{abstract}

Kata kunci: Mikroalga, Perairan Muara, Sungai Pelangan, dan Sekotong

\begin{abstract}
This study aims to determine the composition, abundance, diversity and species dominance of microalgae which found in estuary waters Pelangan, Pelangan Village District of West Lombok. In this study identified 85 species of microalgae. Species that is most widely identified at the sampling site IV (24 species). Based on the value of percentage importance, Chlorococcum humicola was a dominant species in the sites of I and II : $72.309 \%$ and $74.524 \%$, respectively. Furthermore, in the site of III the species with the highest percentage important value was Coscinodisccus lacustris (55.024\%), and the site of IV Thalassiothrix fruenfeldii was the highest percentage importance value (15.795\%). Meanwhile, in the site of $\mathrm{V}$, the two species with the same percentage importance value $(21.840 \%)$ were Rhizosolenia sp. and Thalassiothrix fruenfeldii. The two species of microalgae which always present in all sampling sites were Chlorococcum humicola and Coscinodisccus lacustris. The species diversity index of microalgae species was low to moderate category. The highest species diversity index occurred in the IV site $\left(\mathrm{H}^{\prime}=3.010\right)$. The highest total abundance $(1,540 \mathrm{ind} / \mathrm{L})$ was recorded in the second site.
\end{abstract}

Keywords : Microalga, Estuary Waters, Pelangan River, and Sekotong 


\section{Pendahuluan}

Lebih kurang tiga perempat bagian dari permukaan bumi tertutup air. Luas total permukaan laut merupakan $71 \%$ dari seluruh luas permukaan bumi. Dari segi ekosistem dapat dibedakan menjadi air tawar, air laut dan air payau. Dari ketiga ekosistem perairan tersebut, air laut dan air payau merupakan bagian terbesar, yaitu lebih dari $97 \%$. Sisanya adalah air tawar yang dibutuhkan oleh manusia dan banyak jasad hidup lainnya untuk keperluan hidupnya (Barus, 2002).

Laut sebenarnya melimpah dengan plankton, yakni tumbuhan dan hewan yang hidupnya melayang atau mengambang dalam air, yang hanyut terbawa oleh arus. Namun, kemelimpahan plankton khususnya fitoplankton dipengaruhi oleh perubahan variabel lingkungan perairan termasuk bahan pencemar. Oleh karena itu, fitoplankton sering dijadikan bioindikator pencemaran dan kerusakan ekosistem perairan. Pada perairan yang tercemar biasanya ditandai dengan keragaman rendah dan adanya ominansi spesies tertentu (Muchlisin, 2000 dalam Jannah, 2012).

Perairan muara adalah perairan yang semi tertutup yang berhubungan bebas dengan laut, sehingga air laut dengan salinitas tinggi dapat bercampur dengan air tawar. Perairan muara ini juga disebut dengan perairan estuari. Perairan estuari secara sederhana dapat diartikan sebagai perairan di sekitar muara sungai. Air di muara sungai merupakan campuran massa air yang berasal dari sungai (air tawar) dengan air laut sekitarnya. Percampuran dari massa air tersebut dapat menyebabkan fluktuasi parameter fisika dan kimia di perairan estuari. Kondisi lingkungan yang selalu berfluktuasi ini akan mempengaruhi organisme dan biota lainnya yang ada di dalamnya, termasuk fitoplankton (mikroalga) yang berperan sebagai produsen dalam tingkatan rantai makanan pada perairan tersebut (Wulandari, 2009).

Menurut Romimuhtarto dan Juwana (2005), jumlah dan keanekaragaman jenis biota yang hidup di laut sangat menakjubkan. Walaupun sudah banyak sekali diketahui jenis-jenis tersebut, ilmuwan masih saja menemukan penghunipenghuni baru, terutama di daerah-daerah terpencil dan lingkungan laut yang dulunya tidak pernah dijangkau orang. Perbedaan keadaan lingkungan di laut sangat besar dan penghuninya pun beranekaragam.

Mikroalga merupakan organisme yang mengandung klorofil serta pigmenpigmen lain sehingga dapat melakukan proses fotosintesis. Mikroalga berukuran mikroskopis, tersebar luas di alam dan dapat di jumpai di semua lingkungan yang terkena sinar matahari, serta morfologi dan ciri-cirinya sangat beragam (Pelezar and Chan, 1986 dalam Sobari et al., 2013).

Penelitian tentang identifikasi mikroalga ini dilakukan pada perairan muara sungai Pelangan Desa Pelangan Kecamatan Sekotong Kabupaten Lombok Barat. Penelitian ini dilakukan karena untuk mengetahui jenis-jenis fitoplankton yang ada pada wilayah tersebut. Karena seperti yang banyak diketahui, bahwa wilayah Sekotong merupakan tempat aktivitas penambangan emas yang dilakukan oleh masyarakat tanpa izin yang menyebabkan perairan di wilayah tersebut tercemar. Kegiatan penambangan tercatat banyak ditemukan di daerah Kecamatan Sekotong khususnya di Pelangan (Rahmawati, 2010). Untuk itu dalam penelitian ini dilakukan identifikasi jenisjenis mikroalga yang ada pada perairan muara sungai tersebut.

\section{Bahan dan Metode}

Sampel air untuk penelitian deskriptif eksploratif ini diambil di lima titik pada perairan Muara Sungai Pelangan Desa Pelangan Kecamatan Sekotong 
Kabupaten Lombok Barat. Kelima titik pengambilan sampel dimaksud adalah satu titik pada bagian hulu sungai, satu titik pada badan aliran sungai, satu titik pada bagian muara sungai (estuari) dan dua titik pada perairan laut. Jarak antar stasiun yaitu sekitar 500 meter. Posisi titik sampling dapat dilihat pada
Gambar 1. Pengamatan laboratorium dan identifikasi mikroalga dilaksanakan di Laboratorium Biologi FMIPA Universitas Mataram.

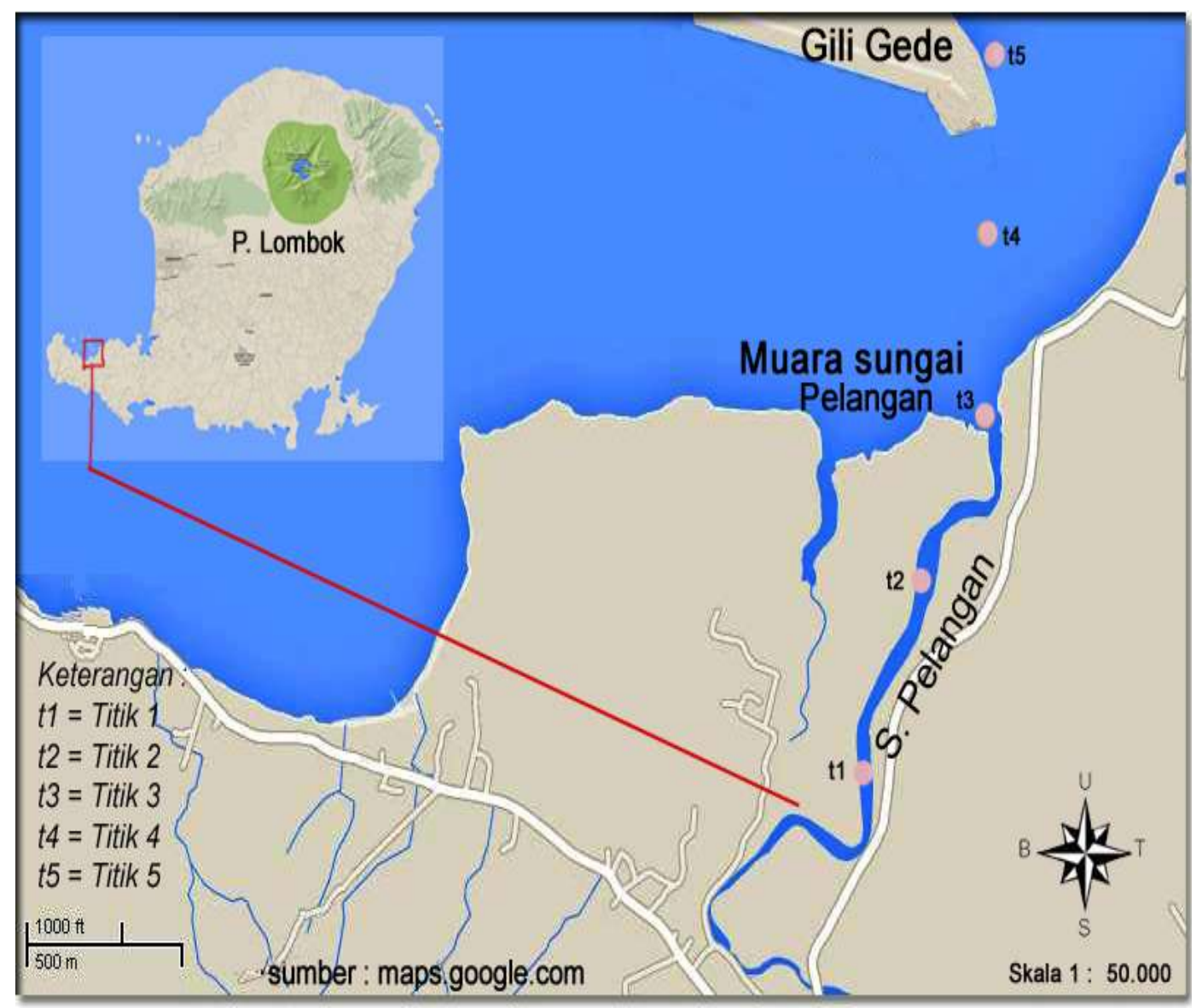

Gambar 1. Lokasi setiap titik pengambilan sampel

Sampel air muara sungai diambil pada kisaran waktu pukul 09.00 - 15.00 wita. Pengambilan sampel mikroalga dilakukan dengan menggunakan jaring plankton dengan diameter mata jaring $20 \mu \mathrm{m}$. Sampel di ambil dengan menyaring 100 liter air pada masing-masing stasiun dengan menggunakan ember sehingga didapatkan sampel yang tertampung di dalam botol jaring plankton sebanyak 25 $\mathrm{ml}$, kemudian dimasukkan ke dalam botol sampel dan diawetkan menggunakan formalin dengan konsentrasi pengawetan $4 \%$.

Sampel yang terdapat dalam botol sampel dihomogenkan terlebih dahulu agar endapan mikroalga yang telah diawetkan dapat tercampur merata. Pencampuran atau penghomogenan dilakukan dengan mengocok sampel secara perlahan-lahan. Setelah itu, diambil sub sampel 1 tetes dengan menggunakan pipet tetes yang memiliki volume $0,05 \mathrm{~mL}$. Selanjutnya sampel diteteskan pada gelas obyek dan 
ditutup dengan gelas penutup, kemudian diamati dibawah mikroskop cahaya. Perbesaran yang digunakan adalah 10x20, dan 10x40. Fitoplankton, diidentifikasi menggunakan buku Smith (1950), Davis, (1955) dan Yamaji (1984). Identifikasi dilakukan dengan cara mencocokkan morfologi dengan gambar yang ada pada buku identifikasi.

Data yang diperoleh kemudian dianalisis secara deskriptif, dan disajikan dalam bentuk tabel dan gambar mikroalga yang diperoleh. Analisis data lebih lanjut meliputi perhitungan kemelimpahan, dominansi, dan indeks keanekaragaman jenis. Kemelimpahan mikroalga atau jumlah rata-rata individu persatuan volume air yang tersaring dianalisis dengan menggunakan rumus dalam Romimuhtarto dan Juwana (2005). Penghitungan indeks keanekaragaman jenis (H') dilakukan dengan menggunakan Indeks Diversitas Shannon-Wiener (Barus, 2002). Dominansi jenis mikroalga ditentukan berdasarkan persentase nilai penting (NP) yang dihitung menggunakan rumus (Surasana dan Taufikurrahman, 1993).

\section{Hasil dan Pembahasan Komposisi Jenis Mikroalga}

Berdasarkan hasil penelitian pada muara sungai Pelangan diperoleh bahwa komposisi mikroalga di perairan tersebut terdiri dari dua divisi yaitu divisi Chrysophyta termasuk dalam kelas Bacillariophyceae (Diatom) yang terdiri dari 17 famili sebanyak 50 jenis dan divisi Chlorophyta termasuk dalam kelas Chlorophyceae terdiri dari 1 famili sebanyak 1 jenis. Komposisi mikroalga yang ditemukan pada kelima titik pengamatan menunjukkan bahwa Divisi Chrysophyta yang paling banyak jenisnya.

Komposisi jenis mikroalga yang ditemukan dalam penelitian ini berdasarkan persentase nilai penting (NP), pada titik I didominansi oleh jenis Chlorococcum humicola dengan jumlah nilai penting sebesar 72,309 \%. Jenis yang lain yang juga mendominasi pada titik I ini yaitu jenis Coscinodisccus lacustris, Pleurosigma angulatum, dan Rhizosolenia sp. Dengan jumlah nilai penting berturutturut sebesar $35,574 \%, 15,846 \%$ dan $15,166 \%$. Pada titik II nilai penting tertinggi (NP) terdapat pada jenis Chlorococcum humicola dan Coscinodisccus lacustris dengan persentase nilai penting masing-masing sebesar $74,524 \%$ dan $26,472 \%$. Begitu juga pada titik III, nilai penting yang tertinggi terdapat pada jenis Coscinodisccus lacustris sebesar 55,024\% dan Chaetoceros van heurckii sebesar 44,498\%, serta Chlorococcum humicola dan Bacteriastrum varians memiliki presentase yang sama yaitu sebesar 28,708\% . Pada titik IV nilai penting tertinggi terdapat pada jenis Thalassiothrix fruenfeldii $(15,795 \%)$, Pseudo-nitzschia sp.2 (14,496\%), dan Rhizosolenia sp. (13,198\%). Sedangkan pada titik $\mathrm{V}$ nilai penting tertinggi terdapat pada jenis Rhizosolenia sp. dan Thalassiothrix fruenfeldii dengan persentase nilai yang sama yaitu sebesar $21,840 \%$. Jenis selanjutnya yang mendominasi pada stasiun ini adalah Chaetoceros laciniosum, Bacteriastrum hyalinum dan Chaetoceros subsecundum dengan persentase nilai penting berturutturut yaitu $18,748 \%, 17,717 \%$ dan $16.686 \%$.

Jenis mikroalga pada masingmasing titik memiliki perbedaan sebaran. Ada beberapa jenis yang dapat ditemukan pada kelima titik pengamatan, diantarnya yaitu jenis Chlorococcum humicola dan Coscinodisccus lacustris. Jenis mikroalga yang hanya ditemukan pada empat titik pengamatan yaitu jenis Pleurosigma angulatum dan Rhizosolenia sp. Sedangkan jenis mikroalga yang ditemukan pada tiga titik yaitu jenis Chaetoceros van heurckii, Gyrosigma fascicola, Gyrosigma strigile 
dan Thalassiothrix fruenfeldii. Keberadaan jenis-jenis mikroalga yang tidak merata pada setiap titik pengamatan tersebut diduga karena daya toleransi antara jenis mikroalga yang satu dengan yang lainnya tidak sama terhadap faktor fisika-kimia lingkungan perairan tersebut. Hal ini sesuai dengan pernyataan Onema (2007) dan Zalocar de Domitrovic et al. (2007) dalam Fachrul et al. (2008), bahwa komposisi mikroalga tidak selalu merata pada setiap lokasi dalam suatu ekosistem, dimana pada suatu ekosistem sering ditemukan beberapa jenis melimpah sedangkan yang lain tidak. Keberadaan mikroalga di suatu kawasan perairan dipengaruhi oleh faktor lingkungannya. Mikroalga membutuhkan kondisi lingkungan perairan yang sesuai dengan kebutuhan hidupnya untuk menunjang kehidupannya (Asriana, 2010).

Perairan muara dikatakan unik karena merupakan tempat bertemunya air tawar dengan air laut sehingga terjadi percampuran dua massa air yang berbeda. Menurut Pritchard 1967 dalam Asriana 2010 menyatakan bahwa kombinasi pengaruh air tawar dengan air laut akan menghasilkan suatu komunitas yang khas dengan kondisi lingkungan yang bervariasi, antara lain yaitu salinitas yang bervariasi. Kisaran ini sesuai untuk pertumbuhan dan perkembangan mikroalga serta bukan merupakan faktor pembatas. Menurut Sachlan (1982) dalam Yuliana et al., (2012) salinitas yang sesuai bagi mikroalga adalah lebih besar dari 20 ppt yang memungkinkan mikroalga dapat bertahan hidup, memperbanyak diri dan aktif melakukan proses fotosintesis.

Mikroalga yang selalu ditemukan pada seluruh titik pengamatan di dominansi oleh jenis Chlorococcum humicola dan Coscinodisccus lacustris. Chlorococcum humicola merupakan divisi Chlorophyta. Menurut Bold \& Wyne (1985), Chlorophyta memiliki range habitat yang luas. Chlorophyta banyak terdapat di danau, kolam, laut. Berdasarkan pendapat Garno (2008) menyatakan bahwa komunitas mikroalga dari divisi Chlorophyta ini kebanyakan hidup di air tawar. Jenis Chlorococcum humicola ini selalu ditemukan disetiap titik pengamatan karena dilihat dari kondisi salinitas perairan pada masing-masing titik pengamatan tidak jauh berbeda, sehingga jenis ini dapat dengan mudah menyesuaikan diri dengan kondisi lingkungan perairannya.

Jenis Coscinodisccus lacustris merupakan divisi Chrysophyta dari kelas Bacillariophyceae (Diatom). Kehadirannya yang selalu ada disetiap titik pengamatan dikarenakan oleh diatom mampu beradaptasi terhadap lingkungan dengan baik. Menurut Arinardi et al., (1997) dalam Wulandari (2009), kelas Bacillariophyceae lebih mampu beradaptasi dengan kondisi lingkungan yang ada karena kelas ini bersifat kosmopolitan serta mempunyai toleransi dan daya adaptasi yang tinggi.

Divisi Chrysophyta yang paling banyak ditemukan jenisnya dalam penelitian ini merupakan mikroalga dari kelas Bacillariophyceae (kelas Diatom). Kelas Bacillariophyceae merupakan jenis diatom yang paling toleran terhadap kondisi perairan seperti suhu dan mampu beradaptasi dengan baik pada lingkungan perairannya sehingga dapat berkembangbiak dengan cepat dan memanfaatkan kandungan nutrien dengan baik (Praseno dan Sugestiningsih, 2000 dalam Nurfadillah et al., 2012). Menurut pendapat Hutomo (1995) dalam Kayanti (2012), menyatakan bahwa kelas Bacillariophyceae sangat mendominasi perairan. Distribusi dari Bacillariophyceae (diatom) ini sangat luas, sehingga dapat ditemukan baik di air tawar maupun air laut (Smith, 1950). Distribusi dan kelimpahan mikroalga sangat dipengaruhi oleh kondisi lingkungan perairan (Soedibjo, 2006 dalam Radiarta 2013). 
Oleh Karena itu sering kali mikroalga (kelimpahan dan indeks ekologinya) dijadikan sebagai bioindikator terhadap kondisi lingkungan perairan (Karydis and Tsirtsis, 1996 dalam Radiarta 2013 ).

\section{Keanekaragaman Jenis Mikroalga}

Total hasil penelitian jenis mikroalga yang ditemukan di perairan muara sungai Pelangan terdiri dari 85 jenis, meliputi 13 jenis pada titik I, 23 jenis pada titik II, 7 jenis pada titik III, 24 jenis pada titik IV dan 18 jenis pada titik V. Jumlah jenis mikroalga pada masing-masing titik pengambilan sampel disajikan pada

\section{Gambar 2.}

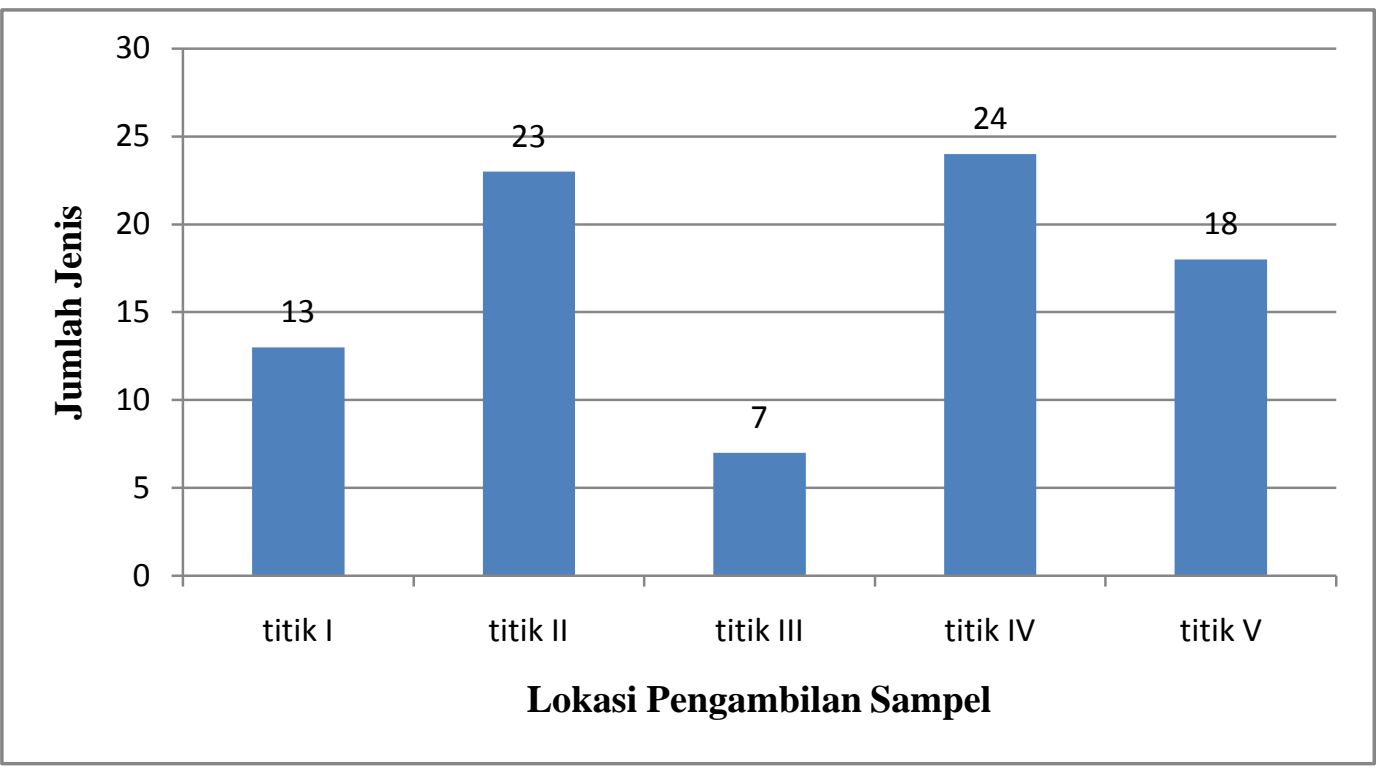

Gambar 2. Jumlah jenis mikroalga pada masing-masing titik pengambilan sampel

Jumlah jenis mikroalga yang ditemukan di masing-masing titik tersebut mempengaruhi tinggi rendahnya indeks keanekaragaman jenis dan kemelimpahan mikroalga di perairan. Semakin tinggi jumlah spesies yang ditemukan, maka indeks keanekaragaman jenisnya juga semakin tinggi. Selain itu faktor fisik-kimia perairan seperti suhu, $\mathrm{pH}$, penetrasi cahaya, dan unsur hara juga sangat berpengaruh terhadap kelimpahan dan keanekaragaman jenis mikroalga. Menurut Odum (1971), perubahan dan kemerataan kekayaan jenis disebabkan oleh ketersediaan unsur hara di perairan sehingga interaksi spesies relatif stabil jika unsur hara tersedia dalam jumlah yang banyak.
Kemelimpahan mikroalga ditentukan oleh jumlah individu yang ditemukan. Semakin banyak jumlah individu, maka semakin tinggi pula kemelimpahannya. Kenaikan jumlah individu (mikroalga) tidak selalu diikuti dengan kenaikan jumlah jenis (Purwanti et al., 2012). Kemelimpahan mikroalga yang ditemukan selama penelitian bervariasi pada setiap titik sampling. Kemelimpahan pada titik I adalah 735 ind/L, titik II adalah 1.540 ind/L, titik III adalah 95 ind/L, titik IV adalah 385 ind/L dan titik V adalah 483 ind/L. Kemelimpahan tertinggi terdapat pada titik II (1.540 ind/L) dan terendah pada titik III (95 ind/L) (Gambar 3). 
Tabel 1. Nilai kemelimpahan dan indeks keanekaragaman jenis pada masing-masing titik pengambilan sampel

\begin{tabular}{clll}
\hline No. & Titik Sampling & $\begin{array}{c}\text { Kemelimpahan Total } \\
\text { (ind/L) }\end{array}$ & Indekskeanekaragaman Jenis \\
\hline 1. & I & 735 & 1,270 \\
2. & II & 1.540 & 1,198 \\
3. & III & 95 & 1,658 \\
4. & IV & 385 & 3,010 \\
5. & V & 485 & 2,580 \\
\hline
\end{tabular}

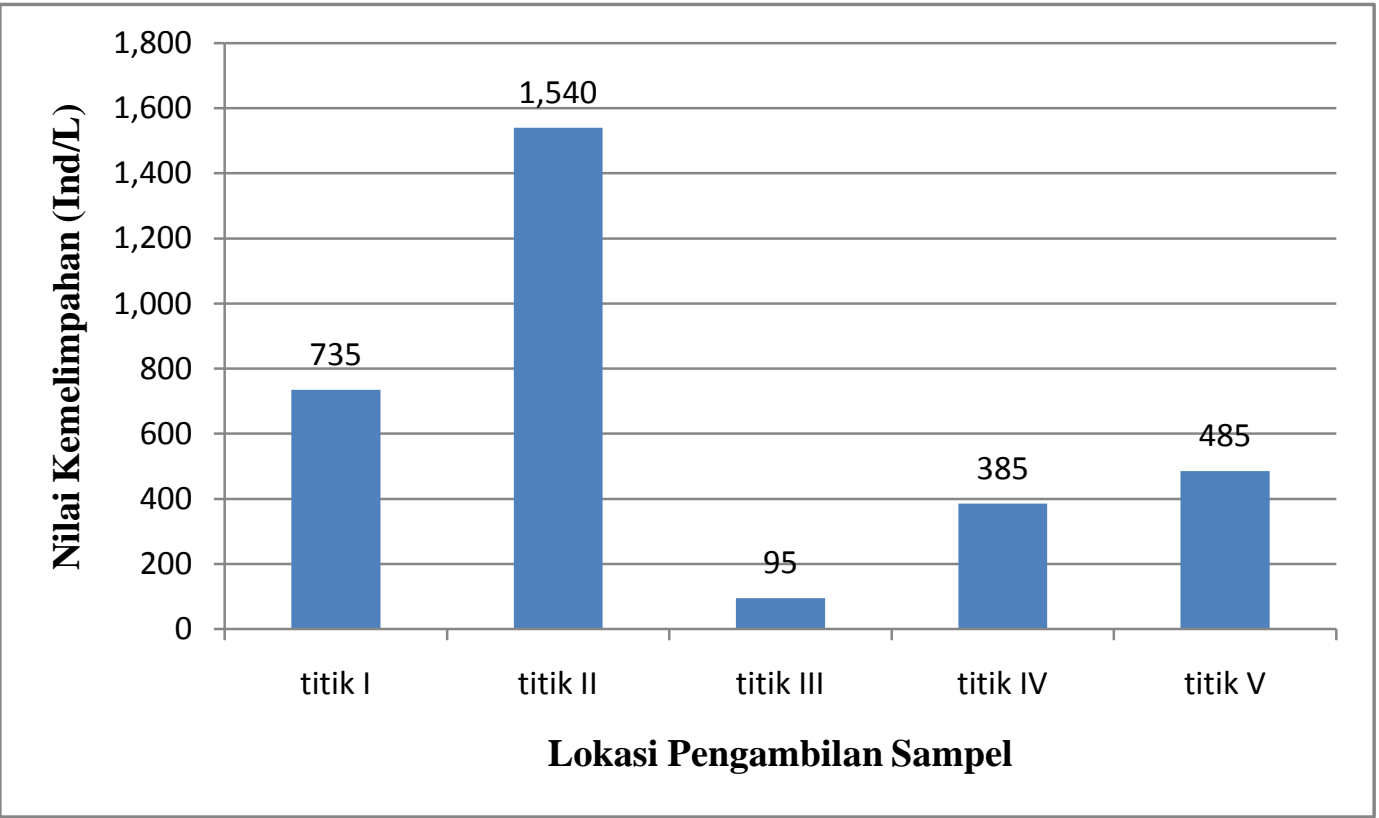

Gambar 3. Nilai kemelimpahan mikroalga di masing-masing titik pengambilan sampel

Tingginya nilai kemelimpahan yang diperoleh pada stasiun II diduga disebabkan oleh parameter-parameter lingkungan yang mempengaruhi kehidupan dan perkembangan mikrolaga pada stasiun ini berada pada kisaran yang sesuai. Suhu dan $\mathrm{pH}$ perairan berada pada nilai yang optimal untuk mendukung kehidupan mikroalga. Suhu pada stasiun II ini yaitu $28^{0} \mathrm{C}$, ini sesuai menurut pendapat Effendi (2003), yang menyatakan bahwa mikroalga akan tumbuh baik pada kisaran suhu $20^{\circ} \mathrm{C}-30^{\circ} \mathrm{C}$. Suhu berperan sebagai pengatur proses metabolisme dan fungsi fisiologis mikroalga. Suhu bukan merupakan faktor pembatas pada mikroalga, namun suhu sangat berpengaruh terhadap percepatan atau perlambatan pertumbuhan dan reproduksi. Perubahan suhu berpengaruh terhadap proses fisika, kimia dan biologi badan air.

Kemelimpahan terendah terdapat pada stasiun III dengan nilai kemelimpahannya yaitu 95 ind/L. Stasiun III merupakan daerah muara, dimana perairan muara merupakan perairan tempat bertemunya air laut dan air tawar sehingga terjadi percampuran dua massa air yang 
berbeda. Kemelimpahan mikroalga di muara sungai lebih sedikit daripada di air laut. Menurut Barnes (1974) dalam Purwanti et al. (2012), jumlah mikroalga di muara sungai umumnya jauh lebih sedikit daripada yang mendiami habitat air laut. Hal ini disebabkan ketidakmampuan plankton air tawar mentolerir kenaikan salinitas dan plankton air laut mentolerir penurunan salinitas muara sungai. Masingmasing jenis mikroalga mempunyai kepekaan yang berbeda dalam memanfaatkan faktor lingkungan secara efektif (Odum, 1993).

Nilai kemelimpahan total dan indeks keanekaragaman jenis ( $\left.\mathrm{H}^{\prime}\right)$ yang diperoleh pada masing-masing stasiun disajikan seperti pada Tabel 1. Keanekaragaman jenis merupakan karakteristik yang unik dari tingkat komunitas dalam organisasi biologi yang diekspresikan melalui struktur komunitas (Barus, 2002).

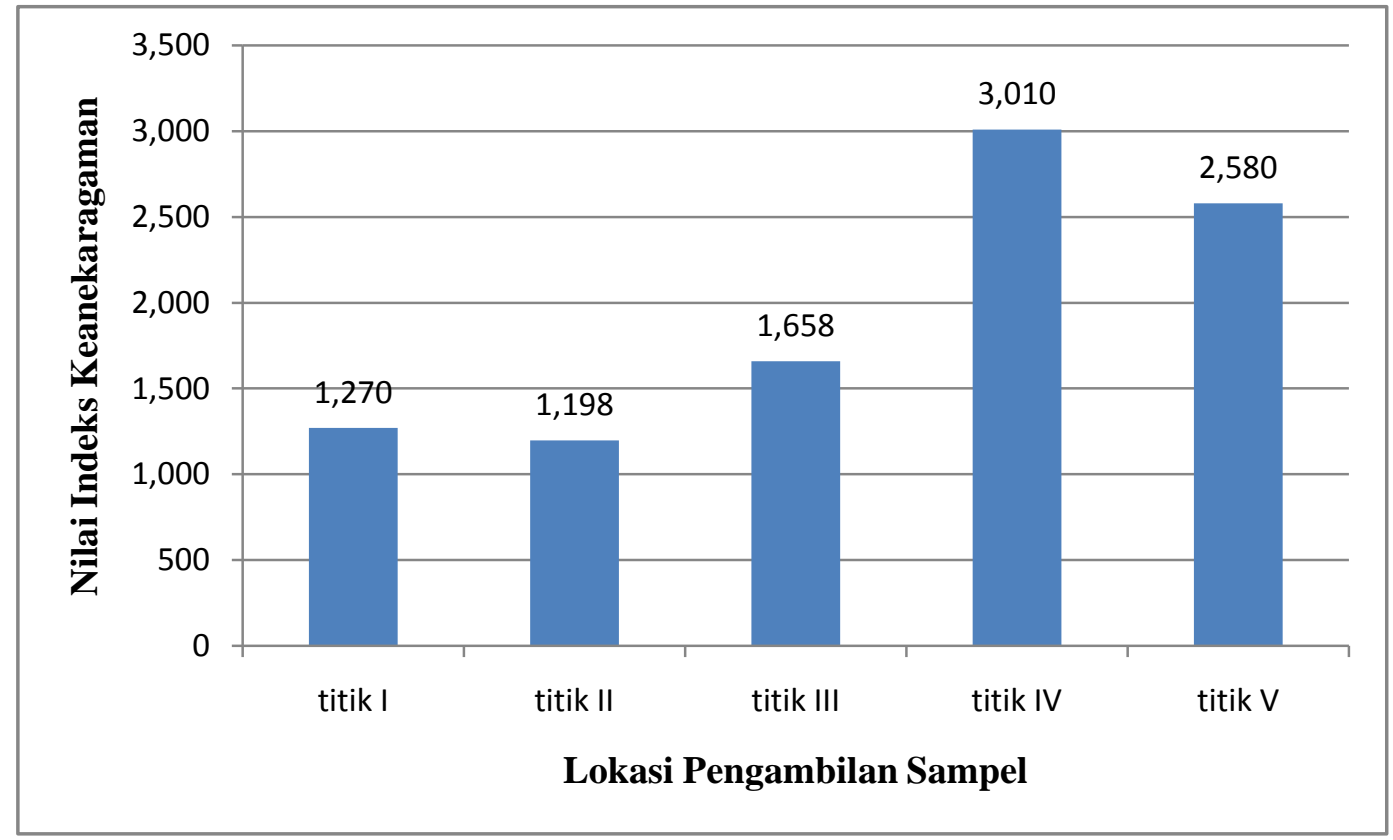

Gambar 4. Indeks keanekaragaman jenis mikroalga di masing-masing stasiun pengambilan sampel

Gambar 4 memperlihatkan indeks keanekaragaman jenis (H') mikroalga pada stasiun I yaitu $(1,270)$, stasiun II $(1,198)$, stasiun III $(1,658)$, stasiun IV $(3,010)$ dan stasiun V yaitu (2,580). Kisaran indeks keanekaragaman jenis ini juga dapat dilihat pada Tabel 1. Berdasarkan kriteria tersebut dapat disimpulkan bahwa masing-masing stasiun penelitian mempunyai tingkat keanekaragaman mikroalga dari kategori rendah-sedang.

Indeks keanekaragaman jenis rendah terdapat pada stasiun I, II dan III, ini terjadi karena pada stasiun-stasiun penelitian itu memiliki sebaran jumlah individu yang tidak merata. Hal ini sesuai menurut pendapat Odum (1998) dalam Asriana (2010) yang menyatakan bahwa indeks keanekaragaman jenis dipengaruhi oleh kekayaan jenis dan kemerataan individu setiap jenis. Apabila terdapat individu yang dominan terhadap yang lainnya, maka indeks keanekaragaman jenisnya rendah.

Rendahnya indeks keanekaragaman jenis pada stasiun I, II dan III juga disebabkan karena stasiun I, II dan III merupakan daerah aliran sungai, dimana 
pada aliran sungai ini terjadi berbagai aktifitas berupa buangan limbah rumah tangga dan temapat aktifitas gelondongan emas yang menyebabkan air sungai menjadi keruh, sehingga mikroalga pada perairan tersebut tidak bisa menperoleh kondisi lingkungan maksimal untuk pertumbuhan dan perkembangannya.

Indeks keanekaragaman jenis sedang terdapat pada titik IV dan V, dimana pada kedua titik ini memiliki sebaran jumlah individu yang relatif sama (merata). Menurut pendapat Barus (2002) yang menyatakan bahwa suatu komunitas dikatakan mempunyai keanekaragaman jenis yang tinggi apabila terdapat banyak jenis dengan jumlah individu masingmasing jenis yang relatif merata. Dengan kata lain, bahwa apabila suatu komunitas hanya terdiri dari sedikit jenis dengan jumlah individu yang tidak merata, maka komunitas tersebut mempunyai keanekaragaman yang rendah. Menurut Bowner et al., (1990) dalam Adawiyah (2013) juga menyatakan bahwa komunitas dikatakan memiliki keanekaragaman yang tinggi bila terdapat kelimpahan yang sama atau hampir sama antara jenis penyusun komunitas. Keanekaragaman jenis yang tinggi menunjukkan kompleksitas suatu komunitas dan variasi yang lebih besar.

Indeks keanekaragaman jenis mikroalga pada titik IV mempunyai nilai tertinggi $\left(\mathrm{H}^{\prime}=3,010\right)$ dari titik yang lainnya karena pada stasiun ini memiliki jumlah jenis paling banyak yaitu 24 jenis dengan jumlah individu 77 yang tersebar merata untuk setiap jenis. Sedangkan untuk titik II dengan indeks keanekaragaman jenis terendah yaitu 1,198 memilik jumlah jenis sebanyak 23 jenis dengan jumlah individu 308, dengan pola penyebaran individu yang tidak merata. Hal ini menunjukkan, bahwa indeks keanekaragaman jenis tidak hanya ditentukan oleh jumlah jenis dan jumlah individu saja, tetapi juga dipengaruhi oleh pola penyebaran jumlah individu pada masing-masing jenis (Barus, 2002).

Pada titik sampling I mempunyai jumlah jenis mikroalga sebanyak 13 jenis dengan 147 individu. Sementara titik III memiliki jumlah jenis paling sedikit yaitu 7 jenis dengan jumlah individu sebanyak 19 dan pola penyebarannya merata. Nilai indeks keanekaragaman jenis mikroalga pada titik III $\left(\mathrm{H}^{\prime}=1,658\right)$ lebih tinggi daripada titik sampling I dengan nilai $\mathrm{H}^{\prime}=$ 1,270 , karena pada titik I pola penyebaran individunya tidak merata. Titik sampling $\mathrm{V}$ memiliki pola penyebaran individu yang merata dengan jumlah individu sebanyak 97, namun memiliki jumlah jenis yang lebih sedikit dibandingkan dengan titik IV yaitu sebanyak 18 jenis. Sehingga indeks keanekaragamannya rendah yaitu $\mathrm{H}^{\prime}=2,580$. Sehingga menurut pendapat Barus (2002), menyimpulkan bahwa nilai indeks keanekaragaman sangat dipengaruhi oleh faktor jumlah jenis, jumlah individu dan penyebaran individu pada masingmasing jenis.

\section{Kesimpulan}

Mikroalga yang ditemukan di perairan sungai dan muara sungai Pelangan terdiri dari 2 divisi yaitu divisi Chrysophyta dan divisi Chlorophyta. Total jenis mikroalga yang ditemukan pada semua titik pengambilan sampel yaitu 85 jenis, meliputi 13 jenis pada titik I, 23 jenis pada titik II, 7 jenis pada titik III, 24 jenis pada titik IV dan 18 jenis pada titik V. Indeks keanekaragaman jenis mikroalga tertinggi $\left(H^{\prime}=3,010\right)$ terdapat pada titik sampling IV, kategori sedang, dan juga dengan jumlah jenis terbanyak (24 jenis) dengan 77 individu. Kemelimpahan total tertinggi (1.540 ind/L) terjadi pada titik sampling II. Sedangkan jenis mikroalga dengan kemelimpahan tertinggi adalah Chlorococcum humicola : 1045 ind/L terjadi pada titik sampling II. Pada titik 
sampling I, II, III berdasarkan nilai penting, jenis yang mendominasi adalah Chlorococcum humicola dan Coscinodisccus lacustris. Sedangkan pada titik IV dan V, jenis yang dominan adalah Thalassiothrix fruenfeldii dengan persentase dominasi masing-masing $15,795 \%$ dan $21,840 \%$.

\section{Daftar Pustaka}

Adawiyah, B.S.R. 2013. Keragaman Spesies Mikroalga Di Perairan Waduk Batujai Dan Waduk Pengga Kabupaten Lombok Tengah. Skripsi. Program S1 Biologi. Fakultas Matematika dan Ilmu Pengetahuan Alam Universitas Mataram.

Asriana, T.S. 2010. Struktur Komunitas Fitoplankton Di Muara Sungai Kota Mataram. Skripsi. Program S1 Biologi. Fakultas Matematika dan Ilmu Pengetahuan Alam Universitas Mataram.

Barus, I.T.A. 2002. Pengantar Limnologi. Universitas Sumatera Utara. Medan.

Bold, H.C. dan M.J. Wyne. 1985. Introduction To the Algae. Practice Hall. USA

Davis, C.C. 1955. The Marine and Freshwater Plankton. Chicago, Michigan State University Press.

Effendi, H. 2003. Telaah Kualitas Air Bagi Pengelolaan Sumberdaya dan Lingkungan Perairan. Penerbit Kanisius. Yogyakarta.

Fachrul, M.F., H.E. Setijati, dan W. Monika. 2008. Komposisi dan Model Kemelimpahan Fitoplankton di Perairan Sungai Ciliwung Jakarta. Jurnal Biodiversitas. Vol. 9(4), 29300.

Garno, Y.S. 2008. Kualitas Air dan Dinamika Fitoplankton di Perairan Pulau Harapan. Jurnal Hidrosfir Indonesia. Vol. 3(2), 87-94.
Jannah, R. 2012. Komunitas Fitoplankton di Daerah Estuaria Krueng Aceh, Kota Banda Aceh. Depik. Vol. 1(3), 189195.

Kayanti, A. D. 2012. Komposisi Jenis Fitoplankton Di Perairan Pelabuhan Poto Tano Sumbawa Barat. Skripsi. Program S1 Biologi. Fakultas Matematika dan Ilmu Pengetahuan Alam Universitas Mataram.

Nurfadillah, A., Damar, dan E.M. Adiwilaga. 2012. Komunitas Fitoplankton Di Perairan Danau Laut Tawar Kabupaten Aceh Tengah Provinsi Aceh. Depik. Vol. 1(2), 9398.

Odum, E.P. 1971. Fundamental of Ecology. Third Edition,.W.B, Sounders.

Odum, E.P. 1993. Dasar-Dasar Ekologi. Edisi ketiga. Terjemahan : Samingan, T., Srigandono. Fundamentals of Ecology. Third Edition. Gadjah Mada University Press. Yogyakarta.

Purwanti, S., H. Riche, dan W. Erry. 2012. Komunitas Plankton Saat Pasang Dan Surut Di Perairan Muara Sungai Demaan Kabupaten Jepara. Laboratorium Ekologi dan Biosistematik. Jurusan Biologi Fakultas Sains $\mathrm{d} c$ tematika Universitas Diponegor rang.

Radiarta, I.N. 2013. Hubungan Antara Distribuusi Fitoplankton Dengan Kualitas Perairan Di Selat Alas Kabupaten Sumbawa Nusa Tenggara Barat. Jurnal Bumi Lestari. Vol. 13 (2), 234-243.

Rahmawati, D. 2010. Identifikasi Kandungan Merkuri Pada Beberapa Muara Sungai di Kecamatan Sekotong Kabupaten Lombok Barat, (http://dc492.4shared.com/doc/cvkkhI 8r/preview.html) [5 April 2013].

Romimuhtarto, K dan S. Juwana. 2005. Biologi Laut: Ilmu Pengetahuan 
Tentang Biologi Laut. Djambatan. Jakarta.

Smith, G.M. 1950. The Freshwater Algae of the United States. Mc Graw-Hill Book Company, INC, New York.Torornto. London.

Surasana dan Taufikurrahman. 1993. Penuntun Praktikum Ekologi Tumbuhan. Jurusan Biologi Fakultas MIPA. Institut Tekhnologi Bandung. Bandung.

Sobari, R., A.B. Susanto, S. Dwi, dan Y.R. Delicia. 2013. Kandungan Lipid Beberapa Jenis Sianobakteria Laut Sebagai Bahan Sumber Penghasil Biodiesel. Jurnal of Marine Research. Vol. 2 (1), 112-119.
Wulandari, D. 2009. Keterikatan Antara Kelimpahan Fitoplankton dengan Parameter Fisika Kimia di Estuari Sungai Berantas (Porong), Jawa Timur. Skripsi. Program S1 Pengelolaan Sumberdaya dan Lingkungan Perairan. Institut Pertanian Bogor.

Yamaji, I. 1984. Illustration of the Marine Plankton of Japan. 3rd edition. Hoikusha Publishing Co. 1td. Japan.

Yuliana., M.A. Enam, H. Enang, dan T.M.P.Niken. 2012. Hubungan Antara Kelimpahan Fitoplanmkton Dengan Parameter Fisik-Kimiawi Perairan Di Teluk Jakarta. Jurnal Akuatika. Vol. III (2), 169-179. 